Pedagogical and political encounters in linguistically and culturally diverse primary classrooms: Examples from Quebec, Canada and Gauteng, South Africa

\author{
Gabrielle Breton-Carbonneau ${ }^{\mathrm{i}}$ \\ Department of Education, Concordia University, 1455 de Maisonneuve Blvd. W., \\ Montreal, Quebec, Canada, H3G1M8 g_breton@education.concordia.ca
}

Ailie Cleghorn (Corresponding author)

Department of Education, Concordia University, 1455 de Maisonneuve Blvd. W., Montreal, Quebec, Canada, H3G1M8 ailie@education.concordia.ca

Rinelle Evans

School for Teacher Training, University of Pretoria, Groenkloof Campus, Pretoria, South Africa revans@up.ac.za

Diane Pesco

Department of Education, Concordia University, 1455 de Maisonneuve Blvd. W., Montreal, Quebec, Canada, H3G1M8 dpesco@education.concordia.ca 


\title{
Pedagogical and political encounters in linguistically and culturally diverse primary classrooms: Examples from Quebec, Canada and Gauteng, South Africa
}

\author{
Abstract \\ Comparative research in multilingual urban primary schools indicates that the \\ pedagogical and political goals of schooling may operate at cross-purposes. \\ Classroom observations and teacher interview-discussions were conducted in \\ classes for immigrant children in Montreal, Quebec, Canada, where the language \\ of instruction is French, and in classes in Pretoria, Gauteng Province, South \\ Africa, where children from many different language backgrounds are taught in \\ English. Two main themes emerged: (1) Pedagogically, effective teacher-learner \\ communication can break down when teachers are unaware of the roles that \\ language and culture play in second language classrooms. (2) Politically, efforts \\ to assimilate learners into new socio-cultural/political contexts sometimes take \\ precedence over sound pedagogical practice, such as drawing on the linguistic \\ and cultural repertoire that learners bring to the classroom. This on-going \\ qualitative research underlines the importance of preparing pre-service and in- \\ service teachers for the linguistic and cultural diversity they are bound to \\ encounter in their classrooms, and of deepening their understanding of the \\ influence of such diversity on the teaching-learning process.
}

Keywords: multilingual; cultural diversity; primary classrooms; instructional language; teacher education 


\section{Introduction}

Primary schools in Montreal, Quebec, Canada and in Pretoria, Gauteng, South Africa offer contrasting socio-linguistic, cultural and political settings for exploring teachers' beliefs about teaching, teacher-learner interactions, classroom arrangements, and activities in highly diverse classrooms. In Montreal, Quebec's largest city with a population of nearly 4 million (Statistics Canada, 2011), immigrant children from many different language and cultural backgrounds are first taught in special welcome classes (classes d'accueil) and continue in French, Quebec's official language of instruction. In Pretoria, Gauteng, South Africa's national capital, with an estimated population of about 2 million (Statistics South Africa, 2003), children who speak many different languages at home are taught in mainstream classes, increasingly in English. Few previous studies have identified common themes in such very different schooling contexts. (For one notable exception see the comparative study on Peru and South Africa by Hornberger and Chick, 2001a and 2001b.)

This paper stems from a qualitative investigation in selected classrooms in Montreal and in Pretoria. Despite the many studies carried out over the last 30 or so years in bilingual and multilingual schools and classrooms, our experience as teacher educators and researchers (especially in the settings under consideration here) as well as reports by other researchers suggest that diversely populated classrooms still offer serious challenges as well as opportunities for teachers and learners alike (Breton-Carbonneau and Cleghorn, 2010; Brock-Utne and Holmarsdottir, 2004; Cleghorn, 2005; Cleghorn and Prochner, 2010; Evans and Cleghorn, 2010; Hawkins, 2004; Holmarsdottir, 2005; Purcell-Gates, 2007; Trueba, Guthrie, and Au, 1981). This paper aims to throw light on 
this matter with particular concern regarding the global expansion of linguistic and cultural diversity among students and the increasing numbers of teachers who are second language speakers of the instructional language.

\section{The context of schooling in Quebec and Gauteng: Some key features}

\section{Quebec $^{i i}$}

Canada has a decentralised educational system, with each of the ten provinces and three territories enjoying a high degree of autonomy with its own education ministry or the equivalent. That is, there is no Canadian federal educational agency that governs or oversees all systems; to this extent Quebec may be considered a de-facto country rather than simply a province.

Historically, the Canadian educational systems were divided along religious lines, with a Roman Catholic system predominating in Quebec. In the mid 1960s, there was a social movement towards a secular Quebec (known as the Quiet Revolution); education then became divided along linguistic lines (French and English). At about this time, the birth rate in the French-speaking population declined dramatically, threatening the viability of the French language in Quebec (Corbo, 2000). When it also became clear that many new immigrants who spoke neither French nor English were choosing English schools for their children and otherwise gravitating towards the English-speaking community, French was perceived as being at ever-increasing risk of disappearing within the North American 'sea of English’ (McAndrew, 2010). Moreover, Quebec nationalism was on the rise and accompanied by a drive to promote French as a cultural resource and French fluency as a marker of a distinct identity (Allen, 2006). In light of these developments, efforts to draw newly arrived immigrants into the French community via 
the French-medium school system were introduced. In 1977, the Quebec Charter of the French Language, now widely known as Bill 101, was passed as law in the Quebec National Assembly. Bill 101 made French the official language of Quebec and the language of instruction for all; a small system of English schools was retained, only for the small minority of English speaking children whose parents had been schooled in English, in Canada ${ }^{\text {iii }}$.

From 1977 onwards, new immigrant students were required to attend Frenchmedium schools. As a result, almost overnight a significant number of learners who did not have a functional knowledge of French began attending French-medium schools alongside learners whose home language was French. To accommodate this influx, a system of classes d'accueil (translated as 'welcome classes') was established. Newly arrived children from other parts of the world were placed in these classes for about one year, and taught subject content such as mathematics, in French, until they had acquired enough French to join mainstream French-medium classes. The welcome class system, which continues today in many schools, was supported by the belief that if newcomers to Quebec learned French, they could then more easily integrate into Quebec society (Gouvernement du Québec, 2001a), and thereby contribute to strengthening the place of the French language. Given Bill 101 and the steady flow of immigrants over the last 35 years, the percentage of immigrant children attending French-medium rather than English-medium schools in Quebec has increased steadily from less than 50\% prior to Bill 101, to $95 \%$ today (McAndrew, 2003; 2010) ${ }^{\text {iv }}$. Since about $87 \%$ of immigrants to Quebec reside in Montreal (Statistics Canada, 2006), most of these children attend Montreal schools. 
Quebec's public schools in the French sector have thus rapidly changed face in terms of ethnic and linguistic diversity. However, the curriculum content and teaching approaches of teacher education programs have not kept pace. For example, very few courses uniquely devoted to cultural and linguistic diversity are required for pre-service teachers, and there is little evidence that these matters are addressed in teacher training curricula more generally. This is the case even though training regarding diversity was described as essential when the current educational policy on interculturalism was established (Gouvernement du Québec, 1998, p. 16) and "cultural mediation" is amongst the competencies presently expected of newly trained teachers (Gouvernement du Québec, 2001b).

In light of these issues, it is important to explore how today's teachers are responding to the diversity they meet in the classroom, and how they are responding to these educational policy objectives: (a) to teach children to communicate and learn in French while adapting to Quebec's unique culture, and (b) to respect the linguistic and cultural diversity of their students (Gouvernement du Québec, 1998) ${ }^{v}$. The research asks how teachers negotiate these dual objectives and implied dual roles as facilitators of children's learning and as agents of socio-political change with a mandate to produce new, French-speaking Quebecers.

\section{Gauteng $^{\text {vi }}$}

Schools in Pretoria (Gauteng) have become linguistically and culturally more diverse since the end of apartheid and the inception of democracy in 1994 in South Africa. Previously, the public educational system, like the society as a whole, was divided along racial lines with schools designated for White, Black, or Coloured learners. 
Although racial issues continue to mark the landscape of South Africa's schools, we have chosen to focus on language issues; much research has been and still is being carried out on the constantly shifting racial situation (see, for example, Jansen, 2009; Soudien and Chisholm, 2004; Vandeyar and Killen, 2006).

During apartheid, in Pretoria's elite schools, white students were taught in Afrikaans or in English throughout their schooling. As was the case across South Africa, the majority of black learners attended quite impoverished schools in the rural and suburban townships ${ }^{\text {vii }}$, often receiving instruction in an African language for at least the first few years then switching to instruction in English (Holmarsdottir, 2005). Indigenous language instruction has declined in Pretoria as families gravitate towards previously 'all white' middle class urban schools where English is increasingly the language of instruction from the outset. Many parents equate being competent in English with increased economic opportunity, and thus want their children exposed to English as early as possible (Cleghorn and Prochner, 2010; Probyn, 2009; Republic of South Africa, 2010).

The pull towards English in Pretoria is occurring despite the official status of nine African languages established in the 1996 constitution and a progressive language-ineducation policy (LiEP) (Republic of South Africa, 2010). The LiEP advocates but does not mandate initial instruction in the mother tongue; it suggests an additive approach to multilingualism that aims to elevate the status of previously marginalised African languages in the schools and contribute to the 'rainbow nation' -- the new South Africa. At the same time, English has historically been of high status in South Africa under both colonial rule and apartheid; that its use is continually spreading fits with contemporary 
national goals of "joining the world stage” (Republic of South Africa, DoE, 2001, p. 38)

(See also Crystal, 2003; Heugh, Siegrühn, and Plüddemann, 1995; Tollefson, 1991;

Tollefson and Tsui, 2004). Thus, in Gauteng, as in Quebec, educational policy suggests

that students join a 'wider' societal context associated with political and economic advantages and requiring adoption of a new language. At the same time, they are encouraged to maintain their home language and ethnic identities.

As Evans and Cleghorn (2010) note elsewhere, increased demands for instruction in English have created new challenges for teachers, including a degree of English proficiency that is adequate for teaching purposes. However, only $8.2 \%$ of the nearly 50 million South Africans claim English as a home language (Statistics South Africa, 2003). This means that the majority of South African teachers are second language speakers of English. In addition, teachers in urban schools may not know the learners' home languages. For example, Gauteng is now home to a significant number of rural-urban migrants and refugees from elsewhere in Africa, including the Congo and Mozambique, bringing some knowledge of French and Portuguese, for example, into the classrooms. In Pretoria, one school that catered to mostly white Afrikaans-speaking learners for more than a century now sees close to 1800 black learners speaking a variety of languages used on the African continent, being taught in English by non-native speakers of English (Afrikaans and African languages). Indeed, in three classes with 148 learners in one primary school, 17 different languages were represented, eight of which are spoken in other parts of Africa (Evans and Cleghorn, 2010).

In comparison with Gauteng, some urban schools in other provinces have a higher concentration of black teachers who speak one or more of the African languages 
of their students. Holmarsdottir (2005) observed teachers in Cape Town (Western Cape province) and noted the frequent translation of content from English to isiXhosa as well as code-mixing and code-switching. She also asked teachers in several grade 4 classrooms to engage their students in a listening and reading comprehension task and found that students receiving English-only instruction performed less well than those exposed to both English and isiXhosa, while students receiving instruction and writing their responses only in isiXhosa performed best. These findings are in line with an earlier study carried out in Kenya among Kikuyu-speaking learners who were being taught in English (Bunyi, 1999; Merritt, Cleghorn, Abagi and Bunyi, 1992). Despite such positive effects, most textbooks and wide-scale student evaluations are in English (Brock-Utne and Holmarsdottir, 2004; Holmarsdottir, 2005).

In addition to becoming 'anglicised', particularly in some regions, schools in South Africa are becoming increasingly 'westernised' (Alexander, 2002; Cannella and Viruru, 2004; Cleghorn and Prochner, 2010) via processes observed elsewhere: educational policy borrowing, the adoption of 'foreign' ideas for inclusion in curricula, and the apparent homogenisation of schooling practices (Penn, 2011; Spreen and Vally, 2006; Steiner-Khamsi, 2004). As noted earlier, South Africa's policy also aims to foster national identity and cohesion by inculcating values of equity and equal opportunity within a racially and inter-culturally integrated 'rainbow nation' (Hunt, 2011; Republic of South Africa, 1995). In light of these dual influences, we ask how teachers prepare students to be members of the new South Africa and, alternatively or simultaneously assimilate students to "western" ways of knowing and behaving via English.

\section{Theoretical underpinnings of the present study}


As suggested above, we ask about teachers' pedagogical and/or political objectives in both settings, each of which has important and differing implications for the climate of learning. On the one hand, teachers might foster a climate of acceptance of 'difference', one that respects and acknowledges the language and culture that learners bring to the classroom. The construction of this kind of classroom atmosphere would be in line with recommendations from studies that use a socio-cultural/linguistic lens to outline teaching approaches that are suitable for diverse groups of learners -- children who are recent immigrants or refugees, children from non-literate homes, children who have little or no contact with the language of instruction in the home community (Benson, 2004; Bouffard and Sarkar, 2008; Bunyi, 1999; Cummins, 2003; Cummins and Hornberger, 2007; Fortune and Tedick, 2008; Genesee, 1993, 2008; Stroud, 2002). Socio-cultural theory emphasises the interconnections between language, culture and context, where language is never decontextualised (Hawkins, 2004). The now established thinking from this body of research underlines the importance of building from what learners already know, especially by acknowledging and tapping into the linguistic and cultural repertoire that they bring from home to the classroom. That is, wherever possible, development of the home language in addition to the instructional language is to be encouraged.

Alternatively, teachers might prioritise assimilation, and thus deny the significance of students' home cultures and languages and their relevance for learning. As researchers on bilingualism have pointed out (e.g., Cummins 2000a, 2000b, 2003), this kind of approach is expected to have a negative effect on the learner's identity and attitude towards learning due to a feeling of rejection by the school. 
Social literacy theory also informs our understanding of diversely populated school settings (see especially Barton, Hamilton, and Ivanic, 2000; Gee, 2008; Street, 2001a, 2001b). Although this theory was first developed with older learners in mind, its relevance to diverse groups of young learners is increasingly noted (Cook-Gumperz, 2006; Purcell-Gates, 2008; Stein, 2008). Social literacy theorists take the position that teaching and learning are always contextualised within societal, political and schoolbased power structures, and all the more so in societies marked by language debates and recent social change (Martin-Jones, Kroon, and Kurvers, 2011). As Pavlenko and Blackledge (2004) state, "In multilingual settings, language choice and attitudes are inseparable from political arrangements, relations of power, language ideologies, and interlocutors' views of their own and others' identities" (p. 1). Therefore, certain identities -- those that are most ideologically similar to those of the dominant group -- are legitimised and valued more than others. In Quebec, this may mean that immigrant learners are expected to adopt a particular new identity, one that supports the commitment to the survival of the French language in the context of the national dominance of English, rather than a dual or mixed identity that incorporates the home culture (Breton-Carbonneau and Cleghorn, 2010). In South Africa, the vision of a national racially-integrated identity is set within the shifting relations between the nine official indigenous language groups, the largely white English- and Afrikaans-speaking peoples (a numerical minority with less and less political power), and the advantages that English fluency is believed to confer on a global scale.

\section{Methodology}

As noted earlier, the current research stems from an on-going qualitative 
exploration of the challenges and opportunities of teaching in linguistically and culturally diverse school settings. The selection of Quebec (as a de-facto country within Canada) and Gauteng in South Africa for comparison at the thematic level is purposeful due to the authors' engagement and on-going experience in related research projects in both locales. The selection of teachers was based primarily on teacher willingness and researcher familiarity with the teachers and their schools. Although efforts were made to involve teachers of different backgrounds, levels of experience, and ages, the sampling was not exhaustive nor was it entirely parallel in the two settings. Nevertheless, the questions we ask and the responses to them across the two settings are relevant to other linguistically and culturally complex schools, where teachers and students are negotiating similar challenges.

Classroom observations were carried out in grades R to 3 in two urban primary schools in Gauteng province of South Africa. These followed earlier classroom observations conducted in the same schools, the results of which appear in Evans and Cleghorn (2010). The two sets of observations were conducted over a cumulative period of several months. In Quebec, observations in grades 1 to 3 welcome classes took place over six consecutive months. The repeated classroom observations were conducted primarily during literacy activities because they are typically rich in language use. Semistructured and open-ended teacher interviews were also conducted with four teachers in each setting. These explored teachers' perceptions of their roles in the diverse (multilingual) second language classroom, their affective orientations towards linguistic and cultural diversity, and their explicit understandings about additional language learning in young children. The interview data were audio-recorded and transcribed. The 
field notes, interview transcripts and audio-recordings were scrutinised for emerging themes to be confirmed, or not, with subsequent classroom observations and discussions with teachers. That is, a common set of codes was developed in an iterative manner over the course of the research. Vignettes that address the principal questions here are discussed below ${ }^{\text {viii. }}$.

\section{The pedagogical and political meet in the classroom}

The reader will recall that we were particularly interested in the ways that teachers perceive their roles in the classroom, as facilitators of diverse children's learning, which we refer to as a 'pedagogical' theme, and/or as agents of socio-political change, which we refer to as a 'political' theme. As expected, close observation of teacher-learner interactions and attention to teachers' choice of words both in the classroom and during discussion interviews yielded quite rich descriptive data. To elaborate, the pedagogical theme refers to the question of how teachers and learners "negotiate the multiplicity of discourse formats" (Kramsch, 2003, p. 269) to arrive at mutual understandings, especially when neither the teacher nor the learners are first language speakers of the instructional language. The political theme becomes evident through teachers' statements and behaviours in relation to the integration if not assimilation of learners into a changing society. While it is indeed the case that much of what goes on in schools and classrooms is indeed political in terms of socialising children for adult roles in the society they live in, we suggest that when the political appears to have a nationalistic edge to it or denies the importance of the learners' linguistic and cultural capital, then the political takes on a negative hue. In the section below we present a selection of vignettes from classroom observations, as well as from discussions with 
teachers, to illustrate the manner in which the pedagogical and political themes were manifested in each setting.

\section{Quebec}

Two of the four teachers (T1 and T2) are descendants of the original Frenchspeakers who settled in Quebec in the $17^{\text {th }}$ century. Both women are in the 20-40 age range. T3 and T4, both in their 40s, were long-term residents of Quebec and fully fluent in French; however, they were from families that had immigrated to Quebec. T3's family was from Bangladesh and Spain, and T4's family was from Egypt. The vignettes below illustrate how these four teachers' interactions with learners differed, as a function of their stated beliefs on the need to promote the French language in Quebec. The reporting here emphasises the political theme, since that was what came through most consistently in the observational data and interviews with these particular teachers.

During one interview, T1's concern with preserving the French language clearly outweighed her concern with what children bring to school in terms of language and culture, from home. She notes, in particular, the threat from English.

For me, the question that is very, very important is that we preserve French. It's an asset. If we all decide to become Anglophones here, we will have lost something, we will have lost a language, and language goes along with culture as well. When other languages are permitted in the classroom, children 'become lazy', rely on translation in their home languages and will never learn French.

Later she continued as follows, seemingly hinting at the need for a strong language policy in order to stabilise the language situation in the 'nation' of Quebec, while also displaying a misconception that learners' countries of origin are officially unilingual. 
It's important that ... we show them [immigrants] clearly what is 'la réalité Québécoise'. Because when they arrive here ... they don't understand how Quebec works. They tell themselves that in their country, they have one official language, it works a certain way, they have strict and clear rules, but when they come here they're already destabilised, and we offer a destabilised society as well ...

To elaborate, by referring to Quebec as destabilised, T1 was implying that Quebec would become more stable with increased numbers of French-speaking residents.

The teachers were asked their opinions about the use of home languages in the classroom, and, more specifically, if at times it would help children to understand or communicate their ideas or needs. T2 had this to say:

I tell myself that the danger of integrating their languages [in the classroom] will open up the possibility to "we can speak our own languages in the welcome class', and they are not here to speak their languages, they are here to learn French.

Later on she elaborated, clearly indicating the presence of a political mission in her teaching.

It is important to be a good model of 'la francophonie', because whether one likes it or not, the teacher is like the Olympic torch of the language and the culture that she teaches.

Classroom observations yielded important data on this political theme. When a child was caught using his or her home language T2 recorded the child's name on the blackboard and later assigned lines as extra homework: “Je dois parler uniquement en Français en classe" [trans: "I must speak only French in class"]. A poster on the classroom wall contained the class rules, this being one of them. 
Learners who had recently arrived in welcome classes and could not yet use French at all tended to be excluded from classroom activities and given solitary busy work. As this extract from the field notes shows, the learner could take an active part in the classroom only when he or she was able to speak a little French.

In groups of two and three, the students are working on storybooks that they are in the midst of writing and illustrating. Sumita, a new student who joined the class the previous week, is told by $\mathrm{T} 2$ to go work by herself at a table in the back of the room. She is given the option of either practicing her script in a calligraphy workbook, or copying words out of a French dictionary. No one in the class speaks Hindi, Sumita's home language (however, she also understands English), so the teacher asks an English-speaking student to explain to her what she is to do. Sumita walks to the back of the classroom looking scared and confused. In contrast, the two teachers ( $\mathrm{T} 3$ and $\mathrm{T} 4$ ), who were from immigrant families, were aware of the need to reinforce the position of the French language but also behaved in ways that suggested they empathised with the learners. For example, although they agreed with the 'speak French' rule of the classroom, they applied it with less strictness, at times turning a blind eye when the learners talked amongst themselves in languages other than French.

\section{Gauteng}

The four teachers involved in this part of the research are white South African women whose home language is Afrikaans. Their ages range from the mid-twenties to the mid-forties. T1 and T2 were pre-service teachers in the midst of their practicum. The two older teachers (T3 and T4) reported clear recollections of the South Africa they grew up in before the end of apartheid in 1994. Their own schooling was in racially segregated 
Afrikaans medium schools, with English taught as a second language; their peers were of the same race. For them, the linguistically and culturally mixed classes are still an adjustment and they have received little or no in-service training to help them understand this new world. The two younger pre-service teachers have become adults since 1994, yet the families they were raised in were accustomed to a racially divided society. According to Jansen (2009) this has caused some confusion, if not personal conflict, in this younger group of teachers. Our classroom observations and discussions with the teachers show that they were consciously oriented towards the pedagogical aspect of their role, but the political regularly crept in.

In the following vignette ${ }^{\mathrm{ix}}$, drawn from classroom observations, we see the unquestioned influence of a colonial past on the curriculum, in a story with culturallyforeign content being told to children in the R grade (kindergarten).

Without any lead-in activity, T2 tells the Grade R learners that she is going to tell them a story entitled 'Froggie's First Kiss'. The children giggle and nudge each other nervously as the love story unfolds. Valentine cards and Mommy being served breakfast in bed seem culturally far-removed from the world of 5-year old Tswana-speaking learners, most of whom live in a nearby congested township. They do, however, react with much interest when the teacher briefly shows them the pictures that support the written text. They have listened closely as they point out the discrepancy between the words "Froggie turned purple with embarrassment after Froggalina had kissed him" and the picture where the illustrator had NOT coloured the creature's face accordingly.

In this case the teacher missed a teaching moment when the story sparked the learners' interest, perhaps unexpectedly. It is also possible that her relatively limited 
ability to use English prevented her from deviating from the script of the lesson and to use English spontaneously.

The next vignette suggests the dual direction of South Africa's policy objectives, referred to earlier. On the one hand one finds elements of an imported curriculum from the English-speaking cultural world, symbolic of the 'world stage' that South Africa looks to its children, as the promise of the future, to join (Republic of South Africa, 2001). On the other hand, young people are reminded of the effort to integrate the nation, socially, racially and politically.

The walls are decorated with many colourful educational and edifying visual materials, most for children, some more suitable for adults ("10 Ways to be a Good Citizen"). Some are commercially produced, others clearly made by the teachers. One contains the lines of nursery rhymes that many children raised in the English-speaking world are told as bedtime stories. "Jack and Jill went up the hill to fetch a pail of water ...”. Another poster shows a multiracial group of children with an inscription depicting the rainbow nation "We are all one family under the same sky".

In the following passage, $\mathrm{T} 3$ highlights the importance of becoming familiar with her students' home backgrounds, but seems unaware of her bias in assuming that everyone in the class celebrates Christmas. Christianity is clearly the dominant religion in South Africa; there is little open evidence of the presence of other religions despite a small Jewish population (about 70,000) and large Asian population (about 1.2 million), some of which is Muslim or Hindu (South African Government Information, 2011). You must respect everyone's different culture and get to learn a bit more about them. For example, when you ask a general question, like "what do you do on 
Christmas?" then you can get these different ideas of what they do on Christmas and it broadens your cultural knowledge ...

In contrast to the Quebec classrooms, students' home languages were not explicitly forbidden in the classrooms observed in Pretoria. Children's use of their home languages was accepted, particularly in peer interactions outside of formal lessons. Teachers, however, were unable to draw on students' home languages for instructional purposes because of their own lack of knowledge of the many indigenous languages spoken by learners. As suggested above, the Afrikaans-speaking teachers displayed difficulty using the designated medium of English for instructional purposes. This next vignette, first reported in Evans and Cleghorn (2010), captures well both the challenges and the missed opportunities that arise when teachers lack awareness of the learners' needs for language support and when their own fluency in the language of instruction is limited.

The Afrikaans-speaking student teacher (T2) uses an English song about ants to teach the concept of rhythm to a Grade 2 class in an inner city school. Fourteen different language backgrounds are represented in this class. The teacher goes through the lesson with the children chanting the song enthusiastically. Her assumption is the learners all know that the English word ant denotes a tiny, sixlegged insect. Despite 30 minutes of repetitive engagement with the song, one child could not draw an ant until he was shown one crawling up the dustbin. The following excerpt provides further evidence that when a teacher is also a second language learner of the instructional language, there are apt to be pedagogical consequences. Here we see again a lost teaching moment when the teacher was not able to elaborate on a student's response, despite it being an appropriate one given the 
wording of the teacher's question.

The student teacher is revising shapes and colours. She intends teaching the word 'oval' but gives a wordy explanation of something egg-shaped. Her elicitation question to the learners is "Where do we also find eggs?" She had intended that learners point to other oval shapes in the classroom. However, the result is that a learner appropriately answers "In the shop." The teacher simply responds with an emphatic "no."

\section{Discussion and conclusion}

To recapitulate the landscapes that provide the dual lens for this research and the subject of this paper, in Quebec, the Quiet Revolution of the 60s led in 1977 to the legalisation of French as the language of instruction for a linguistically and culturally diverse population of learners. Thus, immigrant and refugee children must acquire the language of instruction so that they may adapt to or integrate to a new social and political milieu. The welcome class system focuses on language learning with the aim of integrating learners into regular French-taught classes within a year; however, these are not entirely French-as-a-second-language classes (FSL) since an effort is made to provide the learners with subject content on a par with their same-age peers.

Although approximately 10\% of teachers in Quebec are currently second language speakers of French (Blais and Ouedraogo, 2008), demographic trends indicate that the numbers of teachers who have neither French nor English as their first language will increase in the coming years. This may well create a new ethos in the welcome classes as well as in the regular French-taught classrooms, pointing to an important topic for future research (Berger, Dei, and Forgette-Giroux, 2009). 
With the end of apartheid in 1994 in South Africa, nine African languages in addition to English and Afrikaans obtained official status. Seen as a newly democratic state, South Africa became a beacon for refugees and immigrants from elsewhere in Africa while the flow of families from the rural and suburban townships into the cities rapidly increased. Due to pressure from parent communities that children be taught from the start in English, English is becoming the de-facto instructional language (Probyn, 2009; Republic of South Africa, 2003; 2005; 2010). While the linguistically-mixed classes in South Africa do not officially focus on English language teaching, we suggest that this is their actual function, at least in the Foundation phase (grade $\mathrm{R}$ through grade 3). However, with less than $9 \%$ of the population reporting English as the home language, most South African teachers are, by implication, not fully fluent speakers of English. Despite being quite fluent for everyday purposes, many report difficulties teaching via English, as was evidenced in the examples reported above (Baker, 2005; Cleghorn, 2005; Evans, Gauton, Kaschula, Prinsloo, Ramagoshi, and Taljard 2007; Webb, 2002; 2004). Clearly, when the teacher is also a second language speaker of the instructional language, there are limits on the effectiveness of developing competency in that language among the learners.

The findings so far point to a tension between education policy and classroom reality in both Quebec and Gauteng. Quebec's Policy Statement on Educational Integration and Intercultural Education (Gouvernement du Québec, 1998) encourages respect for children's home languages, lying in direct contrast to the submersion of immigrant and refugee children in special welcome classes where one finds a 'Frenchonly' rule adhered to quite strictly, along with a demand that learners acquire knowledge 
about Quebec culture as part of the established curriculum. Indeed, the latter is contained in the Education Ministry's description of the competencies that children must master before being integrated into regular French-taught classes (Gouvernement du Québec, 2001a). Despite the fact that the four teachers interviewed agreed that children should not lose their home languages, they clearly did not see the welcome class as a space where other languages could be heard. The prevailing assumption, if not explicitly stated belief, was that the welcome class should have very little to do with the students' home languages and cultures. Here then is evidence that assimilative political considerations sometimes operate at the expense of sound pedagogical considerations.

South Africa's National Education Policy Act of 1996 implicitly assumes that teacher graduates are sufficiently proficient in the instructional language to “... appropriately explain, describe and discuss key concepts in the particular learning area/subject/discipline/phase" (Republic of South Africa, 2000, p. 15). Another national policy document states "It is the responsibility of the language teachers to ensure that Language of Learning and Teaching [sic] does not become a barrier to learning" (Republic of South Africa, 2003, p. 21). Yet, it was frequently observed that teachers would repeat explanations verbatim rather than reformulate ideas, seemingly due to their limited English vocabulary and fluency. In addition, we observed that learners often rely on contextual clues for understanding rather than on oral/aural comprehension.

Although additional data are being gathered, two significant concerns arise from this research. The first is a pedagogical concern. When teachers lack native-like fluency in the language of instruction, teaching moments are lost due to the inability to use the language flexibly, to shift from moment to moment when the need arises to 'catch' 
teaching moments. As Hornberger and Chick (2001a) observed under similar circumstances, when teachers are insecure in their use of language, they tend to use 'safe talk' to fill class time by sticking closely to the lesson script, and by using the same stock phrases over and over, rather than reformulating in ways that would help to establish meaning for the learners.

The second concern is a political one with potentially serious pedagogical consequences. When, as we saw in a few welcome classes in Montreal, the political takes on a nationalistic hue, there is a risk that learners will feel isolated by the school system if not also by the country that they have recently come to. As the long-term results of the welcome class system are not yet known, a longitudinal study ought to be carried out to monitor the adaptation and learning of a large sample of immigrant children as they pass through the school system. How do they fare when they are integrated into regular French classrooms? Are they accepted by teachers and peers? How is the home language and linguistic and cultural identity affected?

In conclusion, the evidence so far from this research suggests that it is becoming increasingly important that teacher education programs foster awareness of both the challenges and resources that immigrant students and second language learners bring to the classroom. Pre-service teachers also need knowledge about the contingencies of learning via a second or additional language with particular reference to the sociopolitical context in which they teach. Indeed, since urban classrooms everywhere are increasingly diverse, such training ought to be part of all teacher education programs, not just second language programs (Genesee, 1993). If teachers increasingly find themselves required to act as second language teachers, they also need to feel secure in their 
command of the instructional language. Whether we are referring to South Africa or Quebec or some other multilingual/multicultural part of the world, teachers also need to be able to relate to the learners' experiences as they shift from the home community's language, values, and behavioural norms to the individualistic values and behavioural expectations that tend to come along with a western form of schooling. As suggested above, when such a shift occurs abruptly without attention to the learners' home languages and cultures, the potential consequences are serious for the learners' ability to understand what is being taught, for the long-term viability of the home language, and for the learners' ethnic and personal identities (Bailey and Nunan, 1996; Cummins, 2000a, 2000b, 2003; Dlamini, 2007; Edwards, 1989; Ramanathan, 2005; Soudien, 2007; WongFillmore, 1991). When teachers have not learned about the intricacies of language and cultural issues in the classroom, it is inevitable that the challenges they experience in teaching tend to be viewed as located within the learner rather than in the system -- that is, in deficit terms. When that occurs, historically-rooted prejudices may find their way into the classroom, defeating the stated integrative ideals of multicultural and intercultural education. 


\section{References}

Allen, D. 2006. Who's in and who's out? Language and the integration of new-immigrant youth in Quebec. The International Journal of Inclusive Education 10, no. 2: 251263.

Alexander, N. 2002. Linguistic rights, language planning and democracy in postapartheid South Africa. In Language policy: Lessons from global models, ed. S. Baker, 116-129. Monterey, CA.: Monterey Institute of International Studies.

Bailey, K. M., and D. Nunan. 1996. Voices from the language classroom. Cambridge: Cambridge University Press.

Baker, S., ed. 2005. Language policy: Lessons from global models. Monterey, CA.: Monterey Institute of International Studies.

Barton, D., M. Hamilton, and R. Ivanic. 2000. Situated literacies: Reading and writing in context. London: Routledge.

Benson, C.A. 2004. Bilingual schooling in Mozambique and Bolivia: From experimentation to implementation. Language Policy 3: 47-66.

Berger, M.J., G. Dei, and R. Forgette-Giroux. 2009. Literacy, diversity and education: Meeting the contemporary challenge. Canadian and International Education Journal 38, no. 1: 1-16.

Blais, J.-G., and S.D.M. Ouedraogo. 2008. A cross-sectional sketch of a few demographic characteristics of teachers in Canada. In Educators' discourses on student diversity within the Canadian educational policy context, ed. D. GérinLajoie (dir.), 29-50. Toronto: Canadian Scholars' Press.

Bouffard, L.A., and M. Sarkar. 2008. Training 8-year-old French immersion students in 
meta-linguistic analysis: An innovation in form-focused pedagogy. Language Awareness 17, no. 1: 3-24.

Breton-Carbonneau, G., and A. Cleghorn. 2010. What's language got to do with it? An exploration into the learning environment of Quebec's classes d'accueil. Canadian and International Education 39, no. 3: 101-121.

Brock-Utne, B., and H.B. Holmarsdottir. 2004. Language policies and practices in Tanzania and South Africa: Problems and challenges. International Journal of Educational Development 24, no. 1: 67-83.

Bunyi, G.W. 1999. Rethinking the place of African indigenous languages in African education. International Journal of Educational Development 19: 337-350.

Cannella, G.S., and R. Viruru. 2004. Childhood and post-colonisation: Power, education and contemporary practice. New York: Routledge Falmer.

Cleghorn, A. 2005. Language issues in African school settings: Problems and prospects in attaining education for all. In Issues in African education: Sociological perspectives, eds. A.A. Abdi and A. Cleghorn, 101-122. New York: PalgraveMacmillan.

Cleghorn, A., and L. Prochner. 2010. Shades of globalization: Views from India, South Africa and Canada. Rotterdam: Sense Publications.

Cook-Gumperz, J. 2006. The social construction of literacy: An unchanging equation. London: Cambridge University Press.

Corbo, C. 2000. Repenser L'école: Une anthologie des débats sur l'éducation au Québec de 1945 au Rapport Parent. Montréal, QC: Les Presses de l’Université de Montréal. 
Crystal, D. 2003. English as a global language. Cambridge: Cambridge University Press.

Cummins, J. 2000a. Language, power, and pedagogy: Bilingual children in the crossfire. Clevedon, England: Multilingual Matters.

Cummins, J. 2000b. "This place nurtures my spirit:" Creating contexts of empowerment in linguistically-diverse schools. In Rights to language: Equity, power and education, ed. R. Phillipson, 249-258. Mawah, NJ: Lawrence Erlbaum.

Cummins, J. 2003. Challenging the construction of difference as deficit: Where are identity, intellect, imagination, and power in the new regime of truth? In Pedagogies of difference: Rethinking education for social change, ed. P. Trifonas, 41-60. London: Routledge.

Cummins, J., and N. Hornberger. eds. 2007. Encyclopaedia of language and education 2nd ed. New York: Springer.

Dlamini, S.N. ed. 2007. New directions in African education. Calgary: University of Calgary Press.

Edwards, J. 1989. Language, society and identity. Oxford: Basil Blackwell.

Evans, R., and A. Cleghorn. 2010. "Look at the balloon blow up!”: Student teacher-talk in linguistically diverse South African foundation phase classrooms. Southern African Linguistics and Applied Language Studies 28, no. 2: 123-133.

Evans, R., R. Gauton, R. Kaschula, D. Prinsloo, R. Ramagoshi, and E. Taljard. 2007. Classroom literacies: Understanding your multilingual classroom. Thornton, S. Africa: Bateleur.

Fortune, T.W., and D. J. Tedick, eds. 2008. Pathways to multilingualism: Evolving perspectives on immersion education. Clevedon, England: Multilingual Matters. 
Gallagher, T., and R. Pritchard. 2007. Assimilation and multiculturalism: Evolving conceptual frameworks. Compare: A Journal of Comparative and International Education 37, no. 5: 567-576.

Gee, J. 2008. Social linguistics and literacies: Ideology in discourses. NY: Routledge. Genesee, F. 1993. All teachers are second language teachers. The Canadian Modern Language Review 50, no. 1: 47-53.

Genesee, F. 2008. Dual language learning in the global village. In Pathways to multilingualism: Evolving perspectives on immersion education, eds. T.W. Fortune and D. Tedick, 253-266. Clevedon: Multilingual Matters.

Gouvernement du Québec. 1998. A school for the future. Policy statement on educational integration and intercultural education. Ministère de l'éducation, des loisirs et des sports. http://www.meq.gouv.qc.ca/REFORME/int_scol/Bro_a.pdf

Gouvernement du Québec. 2001a. Programme de formation de l'école Québécoise : Education préscolaire et enseignement primaire. Chapitre 5.3-Accueil. Ministère de l'éducation, des loisirs et des sports. http://www.mels.gouv.qc.ca/dgfj/dp/ programme_de_formation/primaire/prform2001h.html

Gouvernement du Québec, 2001b. Teacher training: Orientations and professional competencies. Ministère de l'éducation, des loisirs et des sports. http://www.mels.gouv.qc.ca/dftps/interieur/PDF/formation_ens_a.pdf

Hawkins, M.R. ed. 2004. Language learning and teacher education: A sociocultural approach. Clevedon: Multilingual Matters.

Heugh, K., A. Siegrühn, and P. Plüddemann, eds. 1995. Multilingual education for South 
Africa. Johannesburg: Heinneman Publishers (Pty) Ltd.

Holmarsdottir, H.B. 2005. From policy to practice: A study of the implementation of the language-in-education policy (LiEP) in three South African primary schools. PhD diss. University of Oslo. http://www.duo.uio.no/publ/pfi/2005/99096/ Holmarsdottir_avhandling.pdf

Hornberger, N., and J.K. Chick, 2001a. Co-constructing school safetime: Safetalk practices in Peruvian and South African classrooms. In M. Heller and M. MartinJones, eds. Voices of authority: Education and linguistic difference. Vol. 1 of Contemporary Studies in Linguistics and Education, 31-56. Stamford, Connecticut: Ablex.

Hornberger, N., and J.K. Chick, 2001b. Ideological paradox and intercultural possibility: Andean language-in-education policy and practice and its relevance for South Africa. South African Journal of Applied Language Studies 19, no. 3\&4: 215-230.

Hunt, F. 2011. Schooling citizens: Policy in practice in South Africa. Compare: A Journal of Comparative and International Education 41, no. 1: 43-58.

Jansen, J. D. 2009. Knowledge in the blood. Stanford, CA.: Stanford University Press. Kramsch, C. ed. 2003. Language acquisition and language socialization: Ecological perspectives. New York: Continuum.

Martin-Jones, M., S. Kroon, and J. Kurvers. 2011. Editorial, Special Issue. Multilingual literacies in the global south: Language policy, literacy learning and use. Compare: A Journal of Comparative and International Education 41, no. 2: 157164. 
McAndrew, M. 2003. Immigration et diversité à l'école: Le débat Québécois dans une perspective comparative. Montréal, QC: La Presse de l’Université de Montréal.

McAndrew, M. 2010. Les majorités fragiles et l'éducation. Montréal, QC: Les Presses de l'Université de Montréal.

Merritt, M., A. Cleghorn, O. Abagi, and G. Bunyi (1992). Socialising multilingualism: Determinants of codeswitching in Kenyan primary classrooms. Journal of Multilingual and Multicultural Development 13, no. 1 \& 2: 103-121.

Pavlenko, A., and A. Blackledge. eds. 2004. Negotiation of identities in multilingual contexts. Toronto, ON: Multilingual Matters.

Penn, H. 2011. Travelling policies and global buzzwords: How international nongovernmental agencies and charities spread the word about early childhood in the global south. Childhood 18, no. 1: 94-113.

Probyn, M. 2009. 'Smuggling the vernacular into the classroom': Conflicts and tensions in classroom code switching in township/rural schools in South Africa. International Journal of Bilingual Education and Bilingualism 12, no. 2: 123-136.

Purcell-Gates, V. ed. 2007. Cultural practices of literacy: Complicating the complex. Mahwah, NJ: Lawrence Erlbaum.

Purcell-Gates, V. ed. 2008. Cultural practices of literacy: Case studies of language, literacy, social practice and power. New York: Routledge.

Ramanathan, V. 2005. The English-vernacular divide: Postcolonial language politics and practice. Clevedon, Avon, UK: Multilingual Matters.

Republic of South Africa. 1995. White paper on Education and Training. Pretoria: Department of Education. 
Republic of South Africa. 2000. Norms and Standards for Educators. Government Gazette 41, no. 20844. Pretoria: Government printer.

Republic of South Africa. 2001. Education white paper 5 on early childhood education: Meeting the challenge of early childhood development in South Africa. Pretoria. Republic of South Africa. 2003. Revised National Curriculum Statement Grades R - 9, Teachers' Guide for the Development of Learning Programmes (Languages). Pretoria: Department of Education.

Republic of South Africa. 2005. National Curriculum Statement. Pretoria: Department of Education.

Republic of South Africa. 2010. The status of the language of learning and teaching in South African public schools. Pretoria: Department of Basic Education.

Soudien, C. 2007. Schooling, culture and the making of identity in contemporary South Africa. Cape Town: New Africa Books.

Soudien, C., and L. Chisholm. eds. 2004. Constituting the class: An analysis of the process of 'integration' in South African schools. In Changing class: Educational and social change in post-apartheid South Africa. Cape Town: HSRC Press.

South African Government Information. 2011. Religious affiliation (2001 Census Data). http://www.info.gov.za/aboutsa/people.htm (accessed October 18, 2011).

Spreen, C.A., and S. Vally, 2006. Education rights, education policies and inequality in South Africa. International Journal of Educational Development 26, no. 4: $352-362$.

Statistics Canada. 2006. Immigration in Canada: A portrait of the foreign-born population in 2006 census: Immigrants in the provinces and territories. Quebec: 
Highest proportion of foreign-born population ever. http://www12.statcan.ca/ census-recensement/2006/as-sa/97-557/p10-eng.cfm

Statistics Canada. 2011. Population of census metropolitan areas. http://www40.statcan.gc.ca/101/cst01/demo05a-eng.htm (accessed October 12, 2011)

Statistics South Africa, 2003. Census in Brief (No 03-02-03) Pretoria: Statistics South Africa. http://www.statssa.gov.za.

Stein, P. 2008. Multimodal pedagogies in diverse classrooms. New York: Routledge.

Steiner-Khamsi, G. ed. 2004. The global politics of educational borrowing and lending. New York: Teachers College Press.

Street, B.V. 2001a. Academic literacies: A critical perspective. Ways of Knowing Journal 1, no. 1: 19-23.

Street, B.V. ed. 2001b. Literacy and development: Ethnographic perspectives. London: Routledge.

Stroud, C. 2002. Towards a policy for bilingual education in developing countries. Education Division Documents No. 10. Stockholm: Sida.

Tollefson, J.W. 1991. Planning language, planning inequality: Language policy in the community. London: Longman.

Tollefson, J.W., and A. B. M. Tsui. eds. 2004. Medium of instruction policies: Which agenda? Whose agenda? Mahwah, NJ: Lawrence Erlbaum.

Trueba, H., G.P. Guthrie, and H-P. K. Au. 1981. Culture and the bilingual classroom. Rowley, MA: Newbury House.

Vandeyar, S., and R. Killen. 2006. Teacher-student interactions in desegregated 
classrooms in South Africa. International Journal of Educational Development 26, no. 4: 382-393.

Webb, V.N. 2002. Language policy development in post-apartheid South Africa. In Medium of instruction policies: Which agenda? Whose agenda? ed. J.W. Tollefson and A.B. M. Tsui, 217-240. Mawah, NJ: Lawrence Erlbaum.

Webb, V.N. 2004. African languages as media of instruction in South Africa: Stating the case. Language Problems and Language Planning 28: 147-173.

Wong-Fillmore, L. 1991. When learning a second language means losing the first. Early Childhood Research Quarterly 6: 323-346. 


\section{Endnotes}

\footnotetext{
${ }^{\mathrm{i}}$ The four authors whose names appear in alphabetical order contributed equally to this article. [Corresponding author: Ailie Cleghorn - ailie@education.concordia.ca]

ii The systems of education in Quebec and Canada may be well known to many readers, but these details are important for those who are not fully familiar with these settings.

iii This means that English-speaking immigrants to Quebec must also attend French-medium schools.

${ }^{\text {iv }}$ A few immigrant parents have challenged the law through the courts and thus gained access to English schools for their children. In most cases this has been out of consideration of severe learning or other disabilities.

' Quebec's policy statement on intercultural education is to be distinguished from Canada's policy of multiculturalism. Multiculturalism is premised on the idea that in Canada there are two official languages, French and English, but there is no official culture. In Quebec, French is the official language, tied closely to the widely-held belief that there is an associated and distinct, if not official, Quebec culture. For discussion of shifts in the concepts of multiculturalism, interculturalism and their links to issues of diversity and assimilation, see Gallagher and Pritchard (2007).

vi South Africa's recent history and its impact on the education system is also well known to most readers. We review its essentials here for the less informed reader.

vii Schools for black leaners in the townships were impoverished because the government-mandated funding formula provided the least for them.

viii Other themes related to matters of ethnicity, race and students' identity formation. These will be discussed in a forthcoming article.

ix This vignette was reported earlier in Evans and Cleghorn, 2010.
} 